\title{
Research on the Innovation and Development of Ideological and Political Work in Colleges and Universities
}

\author{
Wei Liu \\ Xincheng Street 2888, Students' Affairs Division, Jilin Agricultural University, Changchun, Jilin \\ Province 130118, PR China
}

16446288@qq.com

\begin{abstract}
Keywords: Colleges and universities; Ideological and political work; Innovation and development
\end{abstract}

\begin{abstract}
It is an important base that is colleges and universities for ideological and political education of college students. It is an important period for college students' outlook on life, values and world outlook. It is also an important stage for determining what kind of college students have become. This paper expounds the necessity of the innovation and development of ideological and political work in colleges and universities through the dilemma faced by the traditional ideological and political work of colleges and universities and the innovation and development of ideological and political work in colleges and universities. It provides new ideas and new directions for the innovation and development of ideological and political work in colleges and universities Ideological and political work innovation and development possible.

Ideological and political work in colleges and universities is an important part and necessary means to cultivate talents in the new century. It is the political superiority and fine tradition of our party to attach great importance to ideological and political work. With the continuous development of society, the continuous innovation of science and technology, the traditional ideological and political work can not meet the needs of today's education, so the ideological and political work in colleges and universities also need to keep up with the pace of the times, fit the real life, according to the actual needs of students, , To enhance the quality of ideological and political work, to ensure the health of college students become the pillars of the needs of the motherland. Innovation is the necessary means to survive any thing, if only rest on its laurels, sooner or later will be eliminated, so the ideological and political work innovation and development is a means of survival, but more importantly, to benefit college students, students can successfully.
\end{abstract}

\section{The Difficulties Faced By Traditional Ideological and Political Work in Colleges and Universities}

Attention to the Whole, Ignore the Individual. The traditional ideological and political work of colleges and universities is not devoted to the comprehensive development of the individual, but the tool for cultivating the social needs, focusing only on the role of social development, ignoring the perfect human nature, improving the role of personality and quality development, ignoring its own shaping the effect. College educators in the teaching process, the students as a whole, using the same educational philosophy and education methods, all students equally, most students choose according to their own interests to listen to the content taught by educators feel boring Students ignore the important educational content, the traditional ideological and political work in colleges and universities there is such a defect, not according to the characteristics of each student, to take educational methods, which did not pay attention to some students, students can not according to their own The characteristics of the free development, which is difficult to become the motherland needs a variety of talent.

Attention to the Teachers, Ignore the Students. In the traditional ideological and political work of colleges and universities, college students as a passive receiver of education, in a passive position, but a simple recipient, and not according to the students' personal interests, development needs to develop targeted educational content, ignoring the education The importance of the process, neglected the importance of college students to actively participate in learning, ignoring the 
importance of college students to explore innovation, independent discovery, and too much emphasis on the process of teaching teachers and the final teaching results.

Attention to the Common, Ignore the Personality. For a long time, college educators have attached great importance to the problems that most college students often have, and have come up with solutions to this, so as to achieve certain educational effects, but ignore the problems of few students, and these problems are likely to be large Most students have problems, so failed to stop this phenomenon in time. The ideological and political work of colleges and universities has the same educational method and educational content as each student, and can not respect the individuality of each individual education individual and the right of students to choose their own development mode according to their individual characteristics. Students healthy and happy growth, the traditional ideological and political work of colleges and universities there are too many drawbacks.

\section{The Innovation and Development of Ideological and Political Work in Colleges and Universities}

Innovation of Ideological and Political Work Mechanism. First of all to realize that today's ideological and political work in colleges and universities and the traditional ideological and political work is very different, the traditional ideological and political work is a kind of spoon-fed education, every student's education methods monotonous, this kind of education method can not meet the influence of the new media environment. The university can make the ideological and political work a kind of discipline, study the educational methods adopted by the students under different phenomena, and adopt the effective education for different individuals method. Colleges and universities can also be students concerned about the problem, such as: employment, to obtain graduate students, civil servants and other content added to the ideological and political work, so that with the various policies of the university together. Colleges and universities can also establish ideological and political management mechanism, the formation of a scientific organization and management, cultural management, publicity and management system, so as to ensure the smooth operation of ideological and political work.

Create a Good Emotional Atmosphere. Ideological and political work is the educators and college students heart and heart of the exchange, the educators should first put down their shelves as the elderly, the students as their friends, so that students can put their own defense, the educators to talk about their own heart The real idea, so as to achieve the educators and students between the soul, heart and heart blend, emotional talk can be carried out smoothly. So the educator in the conversation with the students before, to choose a feeling easy and small places, this will make the conversation object without pressure, the spirit of pleasure, such as: cafes, parks, dormitories, specialized offices, but to avoid Talk in front of someone else. The external environment is only one of the factors that affect the effect of conversation. The most important thing is the attitude of the educators. When the students communicate with the students, the emotional attitude of the educators will be manifested through his words and deeds, which will affect the students The idea of the show. Therefore, the educators in the conversation process, to show the students are very interested in the guidance of a problem to have full patience, with their own real emotions to stimulate students, went to the hearts of students to achieve the purpose of communication.

Adapting to the Development of the Times and Establishing the New Concept of Internet. With the continuous development of science and technology, the network has penetrated into all aspects of people's lives, its emergence is not the will of people and the transfer of the impact of people have not been ignored, the ideological and political education students also in this way. The influence of the network on the ideological and political work in colleges and universities has both positive and negative aspects. Educators should be deeply aware of these effects, rather than blindly reject the network, and combined with the positive impact of the network, innovation and effective ideological and political work methods. The traditional educational methods, which are mainly taught in the classroom, have been adapted to the current Internet age. The emergence of new educational methods is an inevitable trend. College educators should first change their education 
concept, and continue to broaden their knowledge. Teaching process, do not just confined to the textbook knowledge, to keep pace with the times, and multimedia technology and network technology applied to the classroom, in class, you can build QQ group, Wechat group, push some of the latest news, Anonymous message to solve the problems encountered in student life.

Create a Good Campus Culture Atmosphere. Resist the erosion of various bad thoughts, establish the mainstream value orientation in the campus cultural activities in the position. If the ideological and political work is limited to textbooks, it is on paper, so it can be combined with practical activities, through a variety of activities to improve the efficiency of ideological and political work. Through the various skills competitions, so that college students to learn the professional interest, the pursuit of true knowledge, continuous thinking, mutual cooperation, solidarity, for the pursuit of their own ideals and continue to work hard to carry out a variety of campus cultural activities, such as: Knowledge contest, science and technology activities week, reading month, art festival and other forms, in these campus cultural activities fully embodies the content of ideological and political work for college students to create a good campus culture environment. In addition to the classroom theory of teaching, to innovate the way students are happy to see, accept more ideological and political work.

Optimize the Atmosphere of Personal Ideological and Political Work. Optimize the atmosphere of personal ideological and political work, related to the ability to improve the ideological and political work environment, educators should pay close attention to college students personal social environment, understand the composition and social activities. To help college students away from social bad people, to avoid college students deceived, to help students establish a good dating environment to help students and positive people exchanges. Although the educators play a certain role in the optimization of the individual's ideological and political work atmosphere, the most important thing is that the students themselves have to learn to distinguish right from wrong, to be patient to listen to the teachings and suggestions of educators, to meet any difficulties and actively to educators Ask for help, so healthy and happy growth.

Ideological and Political Work Should be People - oriented, do a Good Job of Human Education and Management: People are the main body of ideological and political work in colleges and universities. The core of ideological and political work in colleges and universities is people-oriented. The innovation of ideological and political work in colleges and universities needs the support of all faculty and staff. Every faculty and staff is required to work hard and earnestly. Ideological and political work at all times to take into account people, uphold the understanding of people, respect for people, the principle of trust, and faculty honestly, to win the support and cooperation of workers. Care about the staff should be reflected in all aspects of the work to be more an encouragement, you can set some incentives and promotion opportunities; more education in the political guide; in life more considerate caring, can help solve the staff most concerned about life Problems and so on. An effective way to do ideological and political work is to motivate people. As much as possible to communicate with the faculty, to understand their ideas, to arrange their favorite positions for faculty, and to be in line with their character, so that faculty can fully tap their job potential, create potential and innovate potential; Can set the target for the staff of a particular position, and to complete the work of the target staff to reward to encourage them to make persistent efforts to create excellent results. Achievement is the goal of ideological and political work, through the creation of opportunities, so that each faculty and workers continue to improve, continue to develop and achieve personal values. Ideological and political work to create a fair and just environment, so that the majority of faculty and staff can have the confidence to continue efforts to achieve self-development. All in all, under the new environment, the ideas and methods of ideological and political work in colleges and universities should be innovated constantly. The goal of ideological and political workers in colleges and universities is to seek benefits for the broad masses of students and faculty.

\section{Conclusion}

Colleges and universities are the base for cultivating specialized talents for the socialist 
modernization construction in China. It is related to the future development of the motherland, and the ideological situation of college students is related to the healthy growth of the university. Therefore, the innovation of ideological and political work in colleges and universities is very important. It is the healthy growth of college students escort. The ideological and political work is the main political superiority of the party and the state and the important content of the party building. The innovation and development of the ideological and political work in colleges and universities is conducive to improving the quality of ideological and political work in colleges and universities and doing the work of party building in colleges and universities. At present, facing the ever-changing social environment, ideological and political work should be combined with new technologies to adapt to the new environment, innovation and development. Inheriting the traditional ideological and political work and pioneering and innovation is unable to divide, they are combined with each other, innovation is based on the traditional development, innovation is advancing with the times, innovation is facing the changing environment inevitable response, any good traditions need to combine new things, the new situation, in order to obtain vitality, and continue to pass on. In the current new environment, college educators first update their educational concepts, create a relaxed personal ideological and political work atmosphere and a good campus culture atmosphere, combined with the network, new media, to improve their own education methods, update their own education content, from the past as a student as a whole into attention to the development of individual students, for different students to take different educational methods, so as to the different areas of the motherland to transport talent, we can see that the ideological and political work of innovation development is imperative.

\section{References}

[1] Mei Chengrui. To promote the ideological and political work in colleges and universities with the campus culture as the starting point [J]. Science and Technology Horizon, 2014, (6).

[2] Fang Min. Ideological and political work in Colleges and Universities Based on humanistic care and psychological guidance [J].Journal of Huanggang Vocational and Technical College, 2014, (2).

[3] Ministry of Education. Strengthen and improve the new situation under the propaganda and ideological work [EB / OL]. China government network, 2015 -01 -20.

[4] Wu Hehua. On the Problems and Solutions of the Ideological and Political Work in Colleges and Universities [J]. Oriental Enterprise Culture, 2014, (3).

[5] Xi Jinping. Leading cadres to love reading books read books to promote learning-oriented political party learning society [N]. People's Daily, 2009-05-14.

[6] Guo Yanli. To strengthen the ideological and political work of college students under the guidance of the spirit of the 18th Party Congress [J]. Inner Mongolia propaganda ideological and cultural work, 2013, (3).

[7] Chen Guihua, Wang Dongwei. On the Elements of Ideological and Political Education in His Series of Speech in Xiaping Ping [J] .Journal of Ideological and Political Work, 2014, (8).

[8] Li Yinghua. Strengthening and Improving the Ideological and Political Work of College Students by Humanism [J]. Education and Vocation, 2014, (5).

[9] Wang Lina, Xue Dongyan. Predicament and Innovation of Ideological and Political Work in Colleges and Universities [J]. Journal of Changchun University of Technology (Higher Education Study Edition), 2014, (4).

[10] Wang Shengzhen, Guo Yuqing. Analysis of ideological and political work in the development of four key points of innovation [J]. Heilongjiang Researches on Higher Education, 2015 (7).

[11] Yun Fujun. Ideological and political work in the development of innovation [N]. Inner Mongolia Daily, 2001-06-14. 